\title{
Diatoms as biomarker in changes of the Lake Zapovednoye state (Evenkia, Russia)
}

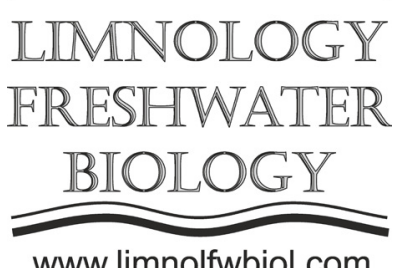

www.limnolfwbiol.com

\author{
Bolobanshchikova G.N. ${ }^{1}$, Rogozin D.Yu. ${ }^{1,2}$ \\ ${ }^{1}$ Federal Research Center "Krasnoyarsk science Center" Siberian Branch of the Russian Academy of Sciences (KSC SB RAS, FRC \\ KSC SB RAS), "Institute of Biophysics Siberian Branch of the Russian Academy of Sciences" (IBP SB RAS) 50/50. Akademgorodok, \\ Krasnoyarsk, 660036, Russia \\ ${ }^{2}$ Siberian Federal University (SibFU) 79 Svobodny, Krasnoyarsk, 660041, Russia
}

\begin{abstract}
As part of a multidisciplinary study aimed at paleoclimatic reconstruction in March 2015 and June 2018 cores of bottom sediments of Lake Zapovednoye (Evenkia, Russia) were obtained. Analysis of samples of bottom sediments by the diatoms composition - one of the main biomarkers or proxy of changes in a state of the lake, showed that, in addition to short-term changes, long-term changes in the species composition of diatoms at least twice occurred. It may be associated with changes in water inflow and level of Lake Zapovednoye. It is most likely these events could occur due to climate change.
\end{abstract}

Keywords: paleoclimate, paleoindicators, bioindicators, proxy, bottom sediments, diatoms.

\section{Introduction}

Diatoms are one of the many bionindicators of changes in the reservoir state. Due to their silica frustulles they are well preserved for many hundreds of years, especially in freshwaters lakes. On the territory of the Krasnoyarsk region there is a large number of unexplored or little studied lakes. One of these lakes is Lake Zapovednoye $\left(60^{\circ} 31^{\prime} \mathrm{N}, 101^{\circ} 43^{\prime} \mathrm{E}\right)$ - a flowing fresh lake located on the Verkhnyaya Lakura River in the territory of the Tungusky State Nature Reserve, $\approx 60 \mathrm{~km}$ from Vanavara. The lake is a round shape, about $500 \mathrm{~m}$ in diameter, a depth about $47 \mathrm{~m}$.

\section{Materials and methods}

In March 2015 and June 2018, cores of bottom sediments of the lake were sampled.The longest core of $124 \mathrm{~cm}$ was cut into $1 \mathrm{~cm}$ slices, which were processed with 30\% hydrogen peroxide (Bolobanshchikova et al., 2018). Fixed samples were prepared using Naphrax and analyzed for diatom composition using light microscopy. (Bolobanshchikova et al., 2018).

Data on the distribution of ${ }^{137} \mathrm{Cs}$ и ${ }^{210} \mathrm{~Pb}$ isotopes over core depths were used to date the upper layers of sediments corresponding to the $20^{\text {th }}$ century. Samples older than the 20th century were dated using radiocarbon analysis on the distribution of ${ }^{14} \mathrm{C}$ isotope.

*Corresponding author.

E-mail address: galina.ibp@mail.ru (G. N. Bolobanshchikova)

\section{Results and discussion}

The analysis of core samples showed that the species composition of diatoms in the thanatocenoses of Lake Zapovednoye is very diverse - about 160 taxa of diatoms were found. The cluster analysis of the quantitative distribution of diatoms helped to divide the changes in diatom assemblage into three large zones (Fig.1). Based on the boundaries of these zones, it can be concluded that at least two long-term changes have occurred in the species composition of diatoms.

The first significant change occurred at the end of the $7^{\text {th }}$ century. A change in the dominant Aulacoseira sp. from Aulacoseira granulata var. angustissima (O.Müll.) Simonsen to a more cold-loving Aulacoseira subarctica (O.Müller) E.Y.Haworth, as well as a sharp decrease in the number of (benthic-planktonic, offer fouling) Tabellaria sp., presumably indicates cooling and a decrease in the amount of precipitation and influx of river water.

From the beginning of this period to the $\approx 14$ 15 centuries, the largest number of Epithemia sp. valves is observed in samples of bottom sediments. All species of this taxon are in symbiotic relationships with nitrogen-fixing cyanobacteria. This may indicate an accumulation of nutrients in the lake at that time, i.e. an increase in the concentration of Nitrogen (N) and Phosphorus (P). Nutrients could cause of surges in numbers of Lindavia lemanensis (Chodat) T.Nakov et al. (planktonic) and Discostella stelligera (Cleve and 


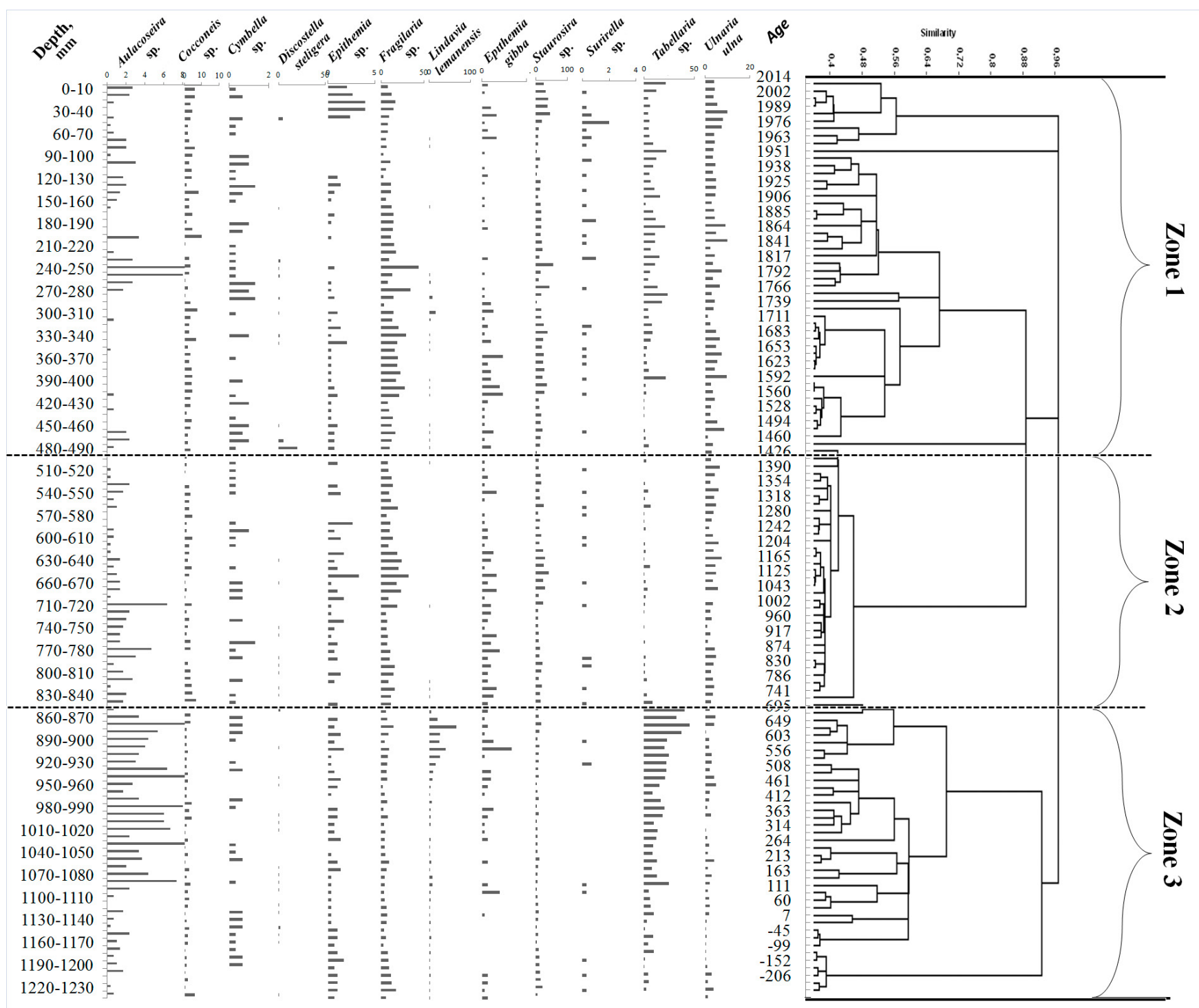

Fig.1. Percentage distribution of diatoms in the bottom sediments of the Lake Zapovednoye.

Grunow) Houk and Kle (planktonic). Since the higher the concentration of these elements in the reservoir, than higher the number of Cyclotella sensu lato (Saros, Anderson, 2015).

The second significant change occurred around the mid to late $15^{\text {th }}$ century. Presumably, this indicates warming and an increase in precipitations and water flow. A sharp increase in the number of Tabellaria sp. may indicate this. Also, this is indirectly indicated by a decrease in the total number of valves of Epithemia sp. This may indicate that it may be associated with a decrease in the concentration of nutrients in the lake due to an increase in the level of the Lake Zapovednoye.

\section{Conclusions}

Based on changes in the species composition of diatoms, we can conclude that in the past the state of the Lake Zapovednoye has repeatedly changed. Presumably, changes in the species composition of diatoms were associated with climate change - conversation from from warm and humid climate to dry and cold and vice versa.

We acknowledge the financial support by the Russian Foundation for Basic Research, grant № 19-0400320.

\section{References}

Bolobanshchikova G.N., Kulikovskiy M.S., Rogozin D.Yu. 2018. Diatoms in the Bottom Sediments of Two Closely Located Lakes in Khakassia. Journal of Siberian Federal University. Biology 11 (4): 321-332.

Saros J.E., Anderson N.J. 2015. The ecology of the planktonic diatom Cyclotella and its implications for global environmental change studies. Biological Reviews 90: 522-541. 